\title{
The Effect of Process Quality and Outcome Quality on Tourist Loyalty in the Hotel Industry
}

Yousef Keshavarz

PhD candidate, Department of Marketing and Management, Faculty of Economics and Management Universiti Putra Malaysia 43400 UPM, Serdang, Selangor, Malaysia.Email: yousef.k73@gmail.com

Prof. Mohd Shahwahid Haji Othman

Department of Economics, Faculty of Economics and Management, Universiti Putra Malaysia 43400 UPM, Serdang, Selangor, Malaysia.Email: mohdshahwahid@gmail.com

\section{Dr. Mass Hareeza Ali}

Department of Marketing and Management, Faculty of Economics and Management Universiti Putra Malaysia, 43400 UPM, Serdang, Selangor, Malaysia.Email: mass@upm.edu.my

\section{Dr. Raja Nerina Raja, Yusof}

Department of Marketing and Management, Faculty of Economics and Management Universiti Putra Malaysia, 43400 UPM, Serdang, Selangor, Malaysia.Email: raja_nerina@yahoo.com

\author{
Doi:10.5901/mjss.2015.v6n6s4p86
}

\section{Abstract}

The present study aims to explore the relationship between process quality and outcom quality with tourist satisfaction and loyalty in the Malaysian hotel industry. In this study, the population comprised international tourists who stayed in one of the 4 and 5-star hotels in Kuala Lumpur. From 537 self-administered questionnaires were distributed, 417 usable responses were obtained. The relationships between 4 constructs (process quality, outcome quality, tourist satisfaction and tourist loyalty) and 39 indicators were measured using structural equation modeling. The results showed that process quality (with six dimensions) and outcome quality (with three dimensions) affect tourist loyalty through mediating role of tourist satisfaction. The results also demonstrated that process quality and outcome quality affect tourist loyalty indirectly through the mediating role of tourist satisfaction. The results of this study will benefit hoteliers in understanding the factors affecting tourist loyalty.

Keywords: process quality, outcome quality, satisfaction, loyalty, hotel.

\section{Introduction}

The rapid growth in hotel industry has led to competing in an ambiguous business environment. Based on their internal strengths, hoteliers can plan competent strategies to attain the best opportunities and market share in the external marketing environment (Rizal, 2008). Reichheld and Sasser (1990) estimated that an increase of 2\% in repeat purchase customers could help an organization to reduce its expenses by $10 \%$ because $60 \%$ of new customers are attracted by word-of-mouth. Therefore, loyalty in the hotel industry plays an important role; a loyal customer in a luxury hotel, for example, both returns and spreads word of mouth, positively (recommendation the hotel to at least 10 people) worth a net present value of more than $\$ 100,000$ (Kotler Bowen, \& Makens, 1999).

However, Berezina et al. (2012) declared that customers might prefer not to revisit a hotel because of not enjoying a previous trip to that destination, preferring to look for a new area, wanting to try new events from the other hotels, or being affected by price and service quality offered by other hotels. Therefore, it is believed that service quality plays a vital role in both attracting and retaining customers (Hansen, 2005; Kim et al., 2007; Choi and Kim, 2013). In the services marketing literature, service encounters are analyzed via two aspects, outcome and process (Grönroos, 1984).

According to Goronroos $(1982,1990)$, outcome quality is the customer perception of what he or she actually obtains from a service provider, and process quality is the manner in which a consumer receives the service. However, 
scholars have recently criticized the fact that most previous studies focused on service quality as a process, whereas outcome quality has not been mentioned as being as important as process quality (Akbaba, 2006; Dabholkar \& Overby, 2005; Luk and Layton, 2004). According to Powpaka (1996), outcome quality is more important in some industries than is process quality; however, the influence of outcome quality on guest satisfaction and loyalty in hotels has not yet been investigated.

The current study provides a model in which the relationships between the variables is described and an integrated model of service quality, including process and outcome quality, tourist satisfaction, and tourist loyalty is suggested for empirical testing. A hypothetical model that links tourist satisfaction with its antecedents and consequences is proposed in the second section. The third part provides the research methodology. In the fourth part, the findings of the research are presented, and the last section suggests the theoretical and managerial implications of the study.

\section{Literature Review}

\subsection{Process Quality}

Links between service quality and customer satisfaction and loyalty have been supported by several studies (Ariffin and Maghzi, 2012; Bojanic, 1996; Fornell, 1992; Hwang and Lambert, 2008; Lloyd, Yip, \& Luk, 2011; Keshavarz \& Ali, 2015; Yang, Peterson \& Cai, 2003). Most measurements of service quality emphasize process quality (Ekinci Prokopaki \& Cobanoglu, 2003; Mei et al., 1999; Mey Akbar, , \& Fie, 2006; Mola and Jusoh, 2011; Poon and Low, 2005; Razalli, 2008; Rizal, 2008). Service quality is an important factor to achieving success in attracting frequent visitors (Akbaba, 2006; Lovelock, 1983; Keshavarz \& Ali, 2015; Saleh and Rayn 1991; So et al., 2013). Researchers analyzed the dimensions of service quality over time. Lehtinen \& Lehtinen (1982) provided three dimensions, including corporate quality, physical quality, and reputation and interactive quality. Parasuraman et al. (1988) suggested five dimensions in the SERVQUAL scale including responsiveness, tangible, assurance, reliability, and empathy. Service quality clarified by Gronroos (1990) include six dimensions including flexibility, and reputation, attitudes and behavior, professionalism and skills, reliability and trustworthiness, credibility and recovery, and accessibility.

Knutson et al. (1990) used the LODGSERV hotel industry scale with five adapted dimensions of SERVQAL. Saleh and Ryan (1991) proposed five dimensions of service quality in the hotel industry containing conviviality, tangibles, reassurance, empathy, and avoiding sarcasm that differed from the SERVQUAL method. Mei et al. (1999) employed the HOLSREV model with three dimensions including employee, tangibles, and reliability. Akbaba (2006) modified the SERVQUAL dimensions for the hotel industry and provided five new dimensions comprising tangible, adequacy in the service supply, understanding and caring, assurance, and convenience. Wilkins, Merrilees, \& Herington (2007) found three main groups of service quality in a hotel, namely the physical product, quality food and beverage, and the service experience.

However, the traditional scales of service quality through HOLSERV, SERVQUAL, and LODGSERV might not be useable to evaluate service quality suitably in the hotel industry (Buttle, 1996; Ekinci, 1998; Mei et al., 1999; Nadiri and Hussain, 2005). Convenience is an important dimension of service quality used in the hotel industry and is not considered in these scales (Akbaba, 2006). In several empirical studies, the effect of convenience as a dimension of service quality on customer satisfaction has been supported (Chan and Wong, 2006; Kim, Ma, \& Kim, 2006; Siu and Cheung, 2001; Yang et al., 2003). Therefore, the question arises: Does convenience, serving as a dimension of process quality, affect tourist satisfaction in synchronization with the LODGSERV scale in the hotel industry?

\subsection{Outcome Quality}

Outcome quality is defined as the "customer's perception of the superiority of the service experience"(Choi and Kim, 2013, p. 190). According to Ro, Choi, and Olson (2013), outcome quality and process quality are recognized as the two main components of service evaluations. Hsieh and Hiang (2004) argued that the customer's perception of outcome quality is a critical factor in assessing service quality. Akbaba (2006) argued that the SEVQUAL model focuses on the service delivery process, whereas outcome quality is ignored in most studies related to service quality. However, a few studies have found that both outcome quality and process quality are essential in customers' evaluation of service quality (Cronin and Taylor, 1992; Powpaka, 1996).

Based on Brady and Cronin (2001), outcome quality has three dimensions: waiting time, tangibles, and valence. Moreover, three dimensions were introduced by Ko and Pastore (2005) with reference to outcome quality: valence, physical change, and sociability. Moreover, according to Fassnacht and Koese (2006) outcome quality has three 
dimensions includs delivery quality, outcome quality and environment quality. Punctuality and valence are two dimensions of outcome quality developed by Caro and Roemer (2006). However, some factors, such as valence, sociability, and waiting time, are suggested by several studies (Caro and García, 2007, 2008; Caro and Roemer, 2006; Brady and Cronin, 2001; Jones and Dent, 1994; Ko and Pastore, 2005; Wu and Ko, 2013).

\subsection{Satisfaction}

According to Vesel and Zabkar (2009), satisfaction is a feeling about a product or service. Wu and Liang (2009) stated that satisfaction is a change in attitude affected by the consumption experience. To meet customers' needs, understanding their demands and recognizing their differences are vital; hence, companies must not only meet their customers' needs but also must know whether they meet their customers' needs. Nilsson and Fundin (2005) argued that customers value a service differently based on their attitude and different conditions.

Bowen and Shoemaker (1998) stated that guests are satisfied if they achieve their expectations in the hotel. Their satisfaction level increased if their perception of service quality exceeded their expectations. This type of tourist satisfaction is essential for tourist loyalty; however, satisfied visitors may not become loyal. Therefore, hotels generally obtain hard satisfaction scores but not necessarily hard loyalty scores (Bowen and Shoemaker, 1998). Olsen (2007) believed that, the relationship between customer satisfaction with customer loyalty is different accross the industries. The reason is that many factors that affect customer satisfaction vary in different industries. Therefore, in this research, tourist satisfaction is considered the mediating variable between process and outcome quality with tourist loyalty.

\subsection{Loyalty}

Loyalty has become the most important strategic target in today's competitive commercial environment (Oliver, 1999). Yoon and Uysal (2005) defined loyalty as the degree of customer intention to re-buy or recommend a special product or service to others. Factors by which hotels can affect tourists' loyalty are still debated. Previous studies have introduced several factors. Ariffin and Maghzi (2012) proposed employees as a vital factor affecting visitor loyalty in hotels. Tanford Raab, and Kim (2012) suggested price, image, amenities, brand, and utility, whereas Chou Hsu, and Chen (2008) underscored location as an important factor affecting customers' satisfaction and loyalty. Several studies suggested service quality as the most important factor affecting customers loyalty in the hotel industry (Lovelock, 1983, Tsaur, Chiu, \& Huang, 2002; So et al., 2013), especially in 4 and 5-star hotels, in which customers have a low tolerance for inefficiency and are more sensitive to hotel services (Mattila, 1999).

In addition, disconfirmation-expectation theory supports the premise that customer satisfaction contributes to customer loyalty (Oliver, 1980). Several studies support a correlation between customer satisfaction and loyalty in a variety of industries (Lai, Griffin, \& Babin, 2009; Rauyruen and Miller, 2007), such as hotel industry (Cronin et al., 2000; Lai et al., 2009; Yang \& Peterson, 2004). However, Heskett, Sasser, \& Schlesinger (1997) maintained that the relationship between satisfaction and loyalty was the weakest link in the hotel industry. Therefore, this research examines the effects of process and outcome quality on tourist loyalty by mediating role of tourist satisfaction in the 4 and 5 -star hotels in Kuala Lumpur, Malaysia.

\subsection{Research Hypotheses}

The current study examined the relationships between four latent variables including process quality, outcome quality, tourist satisfaction, as well as tourist loyalty. Therefore, the formulated hypotheses based on the literature review are provided below:

$\mathrm{H1}$ : Process quality has a positive direct effect on tourist satisfaction.

H2: Process quality has a positive direct effect on tourist loyalty.

H3: Outcome quality has a significant effect on tourist satisfaction.

$\mathrm{H} 4$ : Outcome quality has a positive direct effect on tourist loyalty.

H5: Process quality has a positive indirect effect on tourist loyalty by mediating role of tourist satisfaction.

H6: Outcome quality has a positive indirect effect on tourist loyalty by mediating role of tourist satisfaction.

$\mathrm{H} 7$ : Tourist satisfaction has a positive direct effect on tourist loyalty. 


\section{Methodology}

This research is descriptive and non-experimental in nature. To measure characteristics of respondents, descriptive research are usually used (Hair et al., 2007). The current study is therefore designed to use a quantitative research method. Hypotheses are tested in quantitative researches by applying statistical related tools and criteria (Hair et al., 2007).

\subsection{Development of the Model}

The expansion of the model consisted of two phases. In the first step, initial indicators related to each variable were developed based on previous studies (process quality, outcome quality, tourist satisfaction, and loyalty). Eleven experts from the university first evaluated the content adequacy of each item in the questionnaire. They were asked to provide suggestions on understandability and content. A questionnaire then comprising multiple-item measures was developed in the second step.

The independent variables of the study are process quality with six dimensions and outcome quality with three dimensions. Process quality consisted of six dimensions related to services provided during the stay in the hotel. Five dimensions proposed by Knutson et al. (1990) included tangible, reliability, responsiveness, assurance and empathy, were developed in the LODGSERV instrument, and convenience was added following Akbaba (2006). Outcome quality included the three dimensions relating to tourist attitude about service quality after providing the service (valence, waiting time, and sociability) developed by Wu and Ko (2013). Tourist satisfaction as mediator variable and tourist loyalty as a dependent variable included five and six items, respectively. All variables were on a 5-point Likert scale. The questionnaire was then pilot tested with a sample of 32 international tourists who stayed in 4 and 5 -star hotels in Kuala Lumpur. Some items were changed based on the pilot test for the main survey.

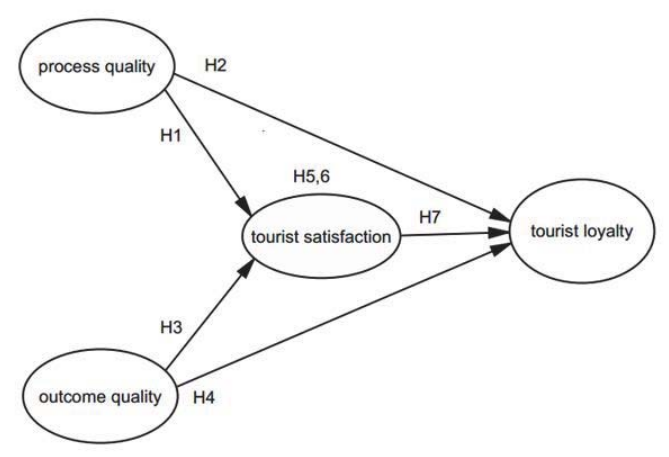

Figure 1: Research Model

\subsection{Sampling and Data Collection}

The population of the study was the international tourists who stayed in 4- and 5-star hotels in Kuala Lumpur. International tourists were selected in 10 famous shopping centers and interesting places in Kuala Lumpur as suggested by the Ministry of Tourism Malaysia. As a screening question, they were first asked if they were staying in a 4- or 5-star hotel in Kuala Lumpur. If they were interested participating, the questionnaire was given to them to answer. Collecting the questionnaire took four weeks, in June and August 2014.

\section{Results}

The sample population consisted of international tourists who stayed in 4- or 5-star hotels in Kuala Lumpur. From the 537 distributed survey questionnaires, 447 were collected. Thirty of the returned questionnaires were eliminated during coding because they were returned blank or were only partially completed. Consequently, 417 questionnaires were valid, which used for data analysis. 


\subsection{Demographics of Respondents}

As shown in Table 1, of the 417 respondents, 291 (69.8\%) were male, and $126(30.2 \%)$ were female. A plurality of respondents were 25 to 34 years of age (34.3\%). The age group of 35 to 44 years (25.4\%) were in second place, followed by 45 to 54 years (17.3\%) and 18 to 24 years (15.6\%). Respondents in the age of 55 to $64(6.5 \%)$ and 65 and more (1\%) were in the last places. Respondents from Asian countries comprised $50.8 \%$ of the sample, followed by Middle Eastern (20.6\%) and European countries (18.2\%); respondents from other countries constituted the smallest group at (10.3\%). A majority of respondents were married (64.3\%). High school degrees were held by $25.9 \%$ of the respondents, whereas $24.7 \%$ had university degrees, $14.4 \%$ had attended college, $30.9 \%$ had a post-graduate education, and $3.1 \%$ were at other education levels. Annual household income of $\$ 20,000$ or less was reported by $36.5 \%$ of respondents, whereas only $10.8 \%$ had an income of $\$ 100,000$ or more. The occupation of a majority of the participants was governmental officer or business owner (49.2\%), followed by other (22.3\%), student (18.5\%), retired (7.7\%), and housewife (2.4\%).

Table 1: Demographic features.

\begin{tabular}{|c|c|c|}
\hline Respondents & Frequency & Percent (\%) \\
\hline \multicolumn{3}{|l|}{ Sex } \\
\hline Male & 291 & 69.8 \\
\hline Female & 126 & 30.2 \\
\hline \multicolumn{3}{|l|}{ Age } \\
\hline $18-24$ & 65 & 15.6 \\
\hline $25-34$ & 143 & 34.3 \\
\hline $35-44$ & 106 & 25.4 \\
\hline $45-54$ & 72 & 17.3 \\
\hline $55-64$ & 27 & 6.5 \\
\hline 65 and more & 4 & 1 \\
\hline \multicolumn{3}{|l|}{ Nationality } \\
\hline Asian countries & 212 & 50.8 \\
\hline Middle East & 86 & 20.6 \\
\hline European countries & 76 & 18.2 \\
\hline Others & 43 & 10.3 \\
\hline \multicolumn{3}{|l|}{ Marital status } \\
\hline Married & 268 & 64.3 \\
\hline Single & 140 & 33.6 \\
\hline Divorced & 8 & 1.9 \\
\hline Separated & 1 & .2 \\
\hline \multicolumn{3}{|l|}{ Earning } \\
\hline Less than $\$ 20000$ & 152 & 36.5 \\
\hline$\$ 20001-\$ 40000$ & 93 & 22.3 \\
\hline$\$ 40001-\$ 60000$ & 57 & 13.7 \\
\hline$\$ 60001-\$ 80000$ & 45 & 10.8 \\
\hline$\$ 80001-\$ 100000$ & 25 & 6 \\
\hline More than $\$ 1000000$ & 45 & 10.8 \\
\hline \multicolumn{3}{|l|}{ Education level } \\
\hline High school degree & 108 & 25.9 \\
\hline Junior college graduate & 60 & 14.4 \\
\hline Bachelor degree & 107 & 24.7 \\
\hline Master degree & 83 & 19.9 \\
\hline Ph. D. & 46 & 11 \\
\hline Others & 13 & 3.1 \\
\hline \multicolumn{3}{|l|}{ Occupation } \\
\hline Student & 77 & 18.5 \\
\hline
\end{tabular}




\begin{tabular}{lcc}
\hline Retired & 32 & 7.7 \\
Housewife & 10 & 2.4 \\
Business Owner & 98 & 23.5 \\
Government Officer & 107 & 25.7 \\
Others & 93 & 22.3 \\
\hline
\end{tabular}

\subsection{Measurement Model}

Table 2 illustrates that the correlation coefficients range from 0.427 to 0.711 and that they are significant $(p<0.001)$. All variables have a significant correlation with tourist loyalty. Furthermore, neither independent variable has significant multicollinearity because these variables had a correlation coefficient less than the recommended value of 0.80 (Hair et al., 2006). The reliability among items of each construct was greater than 0.7 as suggested by Hair et al. (2006).

Table 2: Discriminant validity.

\begin{tabular}{lccccccc}
\hline Variable & Mean & S.D & $\mathbf{\alpha}$ & $\mathbf{1}$ & $\mathbf{2}$ & $\mathbf{3}$ & $\mathbf{4}$ \\
\hline 1) Process quality & 3.667 & 20.235 & .927 & 1 & & & \\
2) Outcome quality & 3.693 & 7.627 & .799 & $.427^{+*+*}$ & 1 & & \\
3) Tourist satisfaction & 3.731 & 3.716 & .920 & $.570^{+*+}$ & $.571^{+*+}$ & 1 & \\
4) Tourist loyalty & 3.385 & 5.063 & .946 & $.596^{+*+}$ & $.521^{*+}$ & $.711^{+*+*}$ & 1 \\
\hline
\end{tabular}

To analyze the validity of the measurement model, confirmatory factor analysis (CFA) was used. Initially, two intercorrelated constructs (process and outcome quality) were verified as two latent variables with nine dimensions and 39 items. The result showed that all factor loadings were significantly greater than 0.7 , but some goodness-of-fit indices, such as CFI and IFI, were less than the recommended value. This contributed to construct revisions. The largest modification indices (MI) values were found in five pairs of residual covariance including reliability (Rel1 and Rel2); Empathy (Emp4 and Emp2); tangible (Tan1 and Tan3); waiting time (Wit2 and Wit3); and Loyalty (Loy5 and Loy3). Consequently, items Rel1, Emp4, Tan1, Wit2 and Loy5 were removed from the model.

The result of the revised model indicated that the model fitted the related data. Table 3 shows that all the loading values for each factor indicators were greater than 0.60 (Hair et al., 2006). Furthermore, the average variance extracted (AVE) values ranged from 0.58 to 0.71 , exceeding the level of 0.5 suggested by Hair et al. (2006). Consequently, discriminant validity was confirmed.

Table 3: The CFA Results.

\begin{tabular}{llcc}
\hline Construct & Items & Loading & AVE \\
\hline Assurance & Asu1 & .83 & \\
& Asu2 & .85 & .647 \\
& Asu3 & .80 & \\
Reliability & Asu4 & .73 & \\
& Rel1 & .83 & .677 \\
Responsiveness & Rel3 & .80 & \\
& Rel4 & .83 & \\
Convenience & Res1 & .83 & .66 \\
& Res2 & .82 & \\
Empathy & Res3 & .78 & \\
& Con1 & .81 & .637 \\
& Con2 & .81 & \\
& Con3 & .78 & \\
& Emp1 & .85 & \\
& Emp2 & .75 & \\
Emp3 & .81 & .577 \\
& Emp5 & .76 & \\
\hline & Emp6 & .75 & \\
Emp7 & .61 & \\
\hline
\end{tabular}




\begin{tabular}{lcll}
\hline Tangible & Tang2 & .70 & \\
& Tang3 & .85 & .642 \\
Tang4 & .81 & \\
Tang5 & .80 & \\
Valence & Tang6 & .83 & \\
& Val1 & .85 & .713 \\
Waiting time & Val2 & .92 & \\
& Val3 & .76 & .675 \\
& Wit1 & .71 & \\
Sociability & Wit3 & .84 & .673 \\
& Wit4 & .91 & \\
& Wit5 & .80 & .83 \\
\hline
\end{tabular}

\subsection{Model fit assessment}

To analyze the hypothesized model, AMOS version 21.0 was developed. The results of model fit measurement are provided in Table 4. The results show that IFI and CFI, as goodness-of-fit indices, were 0.933 for the models, which was greater than the recommended threshold level of 0.9 suggested by Byrne (2010). The RMSEA $=0.058<0.08$. These values show that the hypothesized model is acceptable.

\subsection{Structural Equation Modeling (SEM)}

To investigate the effects of the exogenous constructs of process quality and outcome quality on the endogenous variable of tourist loyalty, causal path analysis was executed. The results of SEM are provided in Table 4 and Figure 2.

Table 4: Structural Model Results.

\begin{tabular}{|c|c|c|c|}
\hline Hypothesis & Regression Weights & C.R. & Results \\
\hline $\mathrm{H} 1$ & .329 & $6.521^{\text {thet }}$ & Supported \\
\hline $\mathrm{H} 2$ & .319 & $6.181^{\text {t+x }}$ & Supported \\
\hline H3 & .633 & $9.635^{\text {thit }}$ & Supported \\
\hline $\mathrm{H} 4$ & .218 & $2.455^{* *}$ & Supported \\
\hline Crodnon of & .565 & $8.149^{\text {tat }}$ & Supported \\
\hline Goodness-of-Fit & & & \\
\hline Chi-Square/Degree of Freedom & 2.102 & & \\
\hline$p$ value & .000 & & \\
\hline RMR & .066 & & \\
\hline GFI & .824 & & \\
\hline AGFI & .802 & & \\
\hline IFI & .933 & & \\
\hline CFI & .933 & & \\
\hline RMSEA & .052 & & \\
\hline
\end{tabular}




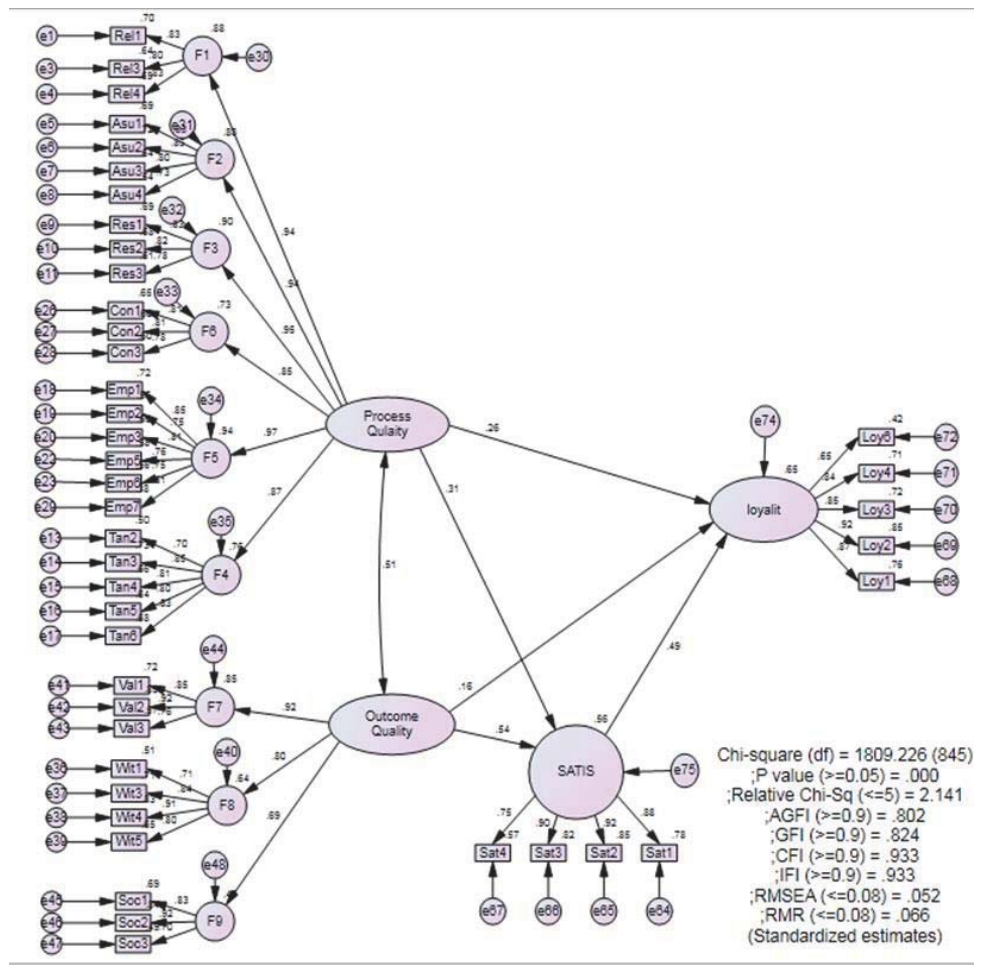

Figure 2: Structural Model

The results provided in Table 4 and Figure 2 show that process quality and outcome quality had a significant influence on tourist satisfaction at the 0.001 level. Therefore, according to the significant influence of process quality and outcome quality on tourist satisfaction, hypotheses 1 and 3 were supported. This result is consistent with the previous findings reporting that a positive relationship existed between process quality and tourist satisfaction (Ariffin \& Maghzi, 2012; Bojanic, 1996; Fornell, 1992; Hwang \& Lambert, 2008; Lloyd et al., 2011; Yang et al., 2003).

Process quality reflects the perceptions about the reliability, assurance, responsiveness, tangible, empathy, and convenience, which are going to be discussed regarding how 4 and 5-star hotels will increase tourist satisfaction. When an international tourist notices that a hotelier has high quality in all kinds of processes, it means that the hotel is more likely to affect them to be satisfied. This finding also supports the results of Luk and Layton's (2004) finding in which outcome quality was identified as substantial for service providers in the hotel industry. The expectancy-disconfirmation theory supports the finding of this study in which customer perception of service quality is caused from the comparison between real service matched with their expectation (Oliver, 1980).

Moreover, the effect of process quality and outcome quality on tourist loyalty was supported at the levels 0.001 and 0.01 respectively. Therefore, according to the significant influence of process quality and outcome quality on tourist loyalty, hypotheses two and four were supported. The results are consistent with the previously reported findings implying in which a positive significant relationship existed between service quality with customer loyalty (Choi \& Kim, 2013; Cronin Brady, \& Hult, 2000; Siu \& Cheung, 2001; Tsaur et al., 2002; Wilkins et al., 2007). Although, the result of these two hypothese were not support Ariffin (2008) and Bigné et al.'s (2009) finding in which tourists were not interested in rebooking the same hotel for the second time because of variety-seeking behaviors.

The dimension valence of outcome quality which provided in the last two hypotheses support the Brady and Cronin's (2001) finding in which the valence was considered as an important factor of outcome quality. Moreover, the dimension of waiting time resulted in this study is consistent with the results provided by Hightower, Brady and Baker's (2002). The sociability dimension result is consistent with Ko and Pastore's (2005) finding in which sociability was identified as an important component of outcome quality. 
Finally, tourist satisfaction influence tourist loyalty positively at the $p$ value less than 0.001 . Therefore, hypothesis 7 was supported. That is, tourists who were satisfied by the high quality services provided by the hotel were more likely to be loyal to the hotel. The mentioned result supports the previous findings highlighting that a customer loyalty is affected positively by customer satisfaction (Cronin et al., 2000; Lai et al., 2009; Yang \& Peterson, 2004)) but it was against the results of few studies such as Heskett et al. (1997) in hotel industry.

\subsection{The mediation effects of tourist satisfaction}

To examine the mediating effects of tourist satisfaction in the relationship between process quality and outcome quality with tourist loyalty, multi-model analysis was implemented. Two models were used to test the mediation effects of tourist satisfaction, the full mediation and the indirect models.

As shown in Table 5, goodness-of-fit indices, such as CFI and IFI, for both models ranged from 0.925 to 0.933 ; both were greater than the recommended value 0.9. In addition, the RMSEA values for both the full mediation and the indirect models (.052 and .054, respectively) were less than the recommended level of .08, implying that the fit of both models is satisfactory.

Table 5: Model Fit Summary

\begin{tabular}{lccccccccc}
\hline Model & NPAR & CMIN & DF & P & CMIN/DF & RMSEA & CFI & TLI & IFI \\
\hline Full Mediation Model & 101 & 1809.226 & 845 & 0.000 & 2.141 & 0.052 & 0.933 & 0.928 & 0.933 \\
Indirect Model & 99 & 1857.452 & 847 & 0.000 & 2.193 & 0.054 & 0.930 & 0.925 & 0.930 \\
\hline
\end{tabular}

Although both models fitted the data adequately, the AIC (Akaike Information Criterion) in the full mediation model was smaller than the indirect model (2894.817 and 3610.623, respectively). Moreover, the PNFI (parsimony normed fit index) value for the full mediation model (0.832) was greater than the PNFI value for the indirect model $(0.804)$. Based on Hooper, Coughlan, and Mullen (2008), the smaller value of AIC and a greater value of PNFI suggest a good fitting model. Therefore, the full mediation model was preferred.

Table 6: Estimates in the Full Mediation, Indirect, and Direct Models

\begin{tabular}{|c|c|c|c|c|}
\hline DV & IV & Mediation Model & Indirect Model & Direct Model \\
\hline Tourist satisfaction & Process quality & $.313^{\text {ktk }}$ & $.332^{k+k t}$ & ------ \\
\hline Tourist loyalty & Process quality & $.264^{\star \star *}$ & -------- & $.504^{\star \star \star}$ \\
\hline Tourist satisfaction & Outcome quality & $.542^{\star \star \star}$ & $.544^{\star \star *}$ & ------ \\
\hline Tourist loyalty & Outcome quality & $.163^{*}$ & ------- & $.573^{* k *}$ \\
\hline Tourist loyalty & Tourist satisfaction & $.492^{* k+}$ & $.778^{* * *}$ & ------ \\
\hline
\end{tabular}

Notes: ${ }^{*} \mathrm{P}<0.05 ;{ }^{* * P}<0.01,{ }^{* * *} \mathrm{P}<.001$

The results, as displayed in Table 6, reveals that, the process quality had a significant posetive relationship with tourist loyalty in the direct model, $(\beta=0.504, p<0.001)$. However, in the full mediation model, this path was significant but the $\beta$ was reduced $(\beta=0.264, p<0.001)$. Hence, tourist satisfaction partially mediated the relationship between process quality and tourist loyalty and hypothesis 5 was supported. That is, tourists who perceived highly process quality were more likely to be satisfied; therefore, they preferred to be loyal to the hotel.

In addition, the results, as revealed in Table 6 , show that in the direct model, the relationship between outcome quality and tourist loyalty was significant $(\beta=0.573, p<0.001)$. Nevertheless, in the full mediation model, this path was significant but reduced $(\beta=.0163, p<0.05)$. Hence, tourist satisfaction partially mediated on the relationship between outcome quality and tourist loyalty, implying that tourists who perceived highly outcome quality were more likely to be satisfied; hence, they preferred to be loyal to the hotel. Therefore, $\mathrm{H} 6$ was supported.

The results of thses two hypotheses are consistent with Choi and Kim's (2013) findings in which outcome quality affect customer loyalty indirectly through customer satisfaction as a mediator. 


\section{Discussion and Implications}

Loyalty plays an substantial role in the hotel industry (Tanford et al., 2012). The current study suggested a model to provide a more thorough understanding the relationship between process quality (tangible, reliability, responsiveness, assurance, empathy, and convenience) and outcome quality (valence, waiting time and sociability) with tourist loyalty by mediating role of tourist satisfaction in the Malaysian hotel industry. Figure 2 presents the relationship between the different constructs in the model as follows:

- Process quality has positive direct effects on tourist satisfaction and tourist loyalty.

- Outcome quality has positive direct effects on tourist satisfaction and tourist loyalty.

- Tourist satisfaction mediates the relationship between process quality (with six dimensions, tangible, reliability, responsiveness, assurance, empathy, and convenience) and tourist loyalty.

- Tourist satisfaction mediates the relationship between outcome quality (with three dimensions, valence, waiting time and sociability) and tourist loyalty.

\subsection{Theoretical Implications}

This research provided a model to understand the effect of process quality and outcome quality on tourist loyalty mediating by mediating role of tourist satisfaction. Cronin et al. (2000), Kim et al. (2007), and Oh (1999) postulated that there were associations between service quality and loyalty through satisfaction. Therefore, in this research the effects of process quality and outcome quality on tourist loyalty through tourist satisfaction as a mediator were investigated to identify if process quality and outcome quality affect directly and indirectly tourist loyalty. The statistical analyses indicated that tourist satisfaction had mediating effect on the relationship between process quality and outcome quality with tourist loyalty. The positive relationship identified between process quality and outcome quality and tourist loyalty through tourist satisfaction may be interpreted as tourist loyalty being raised as a consequence of experiencing a high quality of process and outcome when tourists were satisfied.

Theoretically, the proposed model is innovative in two aspects. First, the service quality instrument used in this study combines the two variables namely process quality and outcome quality from the LODGSERV model (Knutson et al., 1990) to rebuild the antecedent factor structure of service quality for the tourist loyalty setting. Second, the bridges between process quality, outcome quality, tourist satisfaction, and tourist loyalty were fully established with one combined model based on earlier studies.

\subsection{Managerial Implications}

In an extremely competitive environment such as Kuala Lumpur, hoteliers must consider tourist loyalty as an important factor driven by process and outcome quality. In particular, hotel managers should focus on valence (i.e., experience) as a dimension of outcome quality that presents the essence of tourist satisfaction and loyalty (the greatest path coefficient with tourist satisfaction as dependent construct in Table 4 and Figure 2). It also indicates the importance of "I feel that I have got what I wanted." Hoteliers need to provide what tourists expect from their services. The challenge to hotel managers is to determine the appropriate resource apportionment across process quality, outcome quality, and tourist satisfaction that contributes to tourist loyalty.

Tourist satisfaction is affected by process quality and outcome quality. Improvements in outcome quality and process quality most likely contribute to tourist satisfaction. By analyzing and recognizing these diagnostic indicators, the hoteliers will be able to better formulate and implement their strategic plans. For example, if a hotel manager worries about the guests' loyalty, it is superior to first check if the tourists think that the services provided by the hotel is qualified, and if the tourists feel satisfaction during the stay experience.

\section{Concluding Remarks}

The results of this study demonstrate that, it is important for hotelier to make significant efforts when high levels of tourist satisfaction resulting from better process quality and outcome quality eventually contribute to tourist loyalty. For researchers, outcome quality and process quality should be used in the model designed to understand the separate factors affecting tourist satisfaction and loyalty. Tourist satisfaction needs to be considered by hoteliers in relationship with process and outcome quality when designing and providing services. 
In interpreting the outcomes of this survey, one must pay attention to some limitations. Firstly, this research is focused on limited generalizability because it was conducted in a specific industry (four- and five-star hotels). Secondly, this study examined only international tourists who were staying in a four or five-star hotel in Kuala Lumpur, Malaysia. Experiences in other types of hotels and domestic tourists were not explored. Therefore, it is suggested that future studies use the model for hotels of other ranks (e.g., budget hotels, hostels, etc.) and other areas. Thirdly, discovering more-inclusive models integrating other measures of service quality and tourist satisfaction would be appropriate to further understand of service quality, tourist satisfaction as well as tourist loyalty. Finally, further studies are suggested to explore the effects of special services in hotels (such as children's services) on customer loyalty.

\section{References}

Akbaba, A. (2006). Measuring service quality in the hotel industry: A study in a business hotel in Turkey. International Journal of Hospitality Management, 25(2), 170-192.

Ariffin, A. A. M., \& Maghzi, A. (2012). A preliminary study on customer expectations of hotel hospitality: Influences of personal and hotel factors. International Journal of Hospitality Management, 31(1), 191-198. doi: 10.1016/j.ijhm.2011.04.012

Back, K.-J. (2005). The effects of image congruence on customers' brand loyalty in the upper middle-class hotel industry. Journal of Hospitality \& Tourism Research, 29(4), 448-467.

Berezina, K., Cobanoglu, C., Miller, B. L., \& Kwansa, F. A. (2012). The impact of information security breach on hotel guest perception of service quality, satisfaction, revisit intentions and word-of-mouth. International Journal of Contemporary Hospitality Management, 24(7), 991-1010.

Bojanic, D. C. (1996). Consumer perceptions of price, value and satisfaction in the hotel industry: An exploratory study. Journal of Hospitality \& Leisure Marketing, 4(1), 5-22.

Bowen, J. T., \& Shoemaker, S. (1998). Loyalty: A strategic commitment. Cornell Hotel and Restaurant Administration Quarterly, 39(1), $12-25$.

Brady, M. K., \& Cronin, J. J. J. (2001). Some new thoughts on conceptualizing perceived service quality: a hierarchical approach. Journal of Marketing, 65(3), 34-49.

Buttle, F. (1996). SERVQUAL: review, critique, research agenda. European Journal of Marketing, 30(1), 8-32.

Byrne, Barbara M. (2010). Structural equation modeling with AMOS: Basic concepts, applications, and programming. New York: Routledge

Caro, L. M., \& García, J. A. M. (2007). Measuring perceived service quality in urgent transport service. Journal of Retailing and Consumer Services, 14(1), 60-72.

Caro, L. M., \& García, J. A. M. (2008). Developing a multidimensional and hierarchical service quality model for the travel agency industry. Tourism Management, 29(4), 706-720.

Caro, L. M., \& Roemer, E. (2006). Developing a multidimensional and hierarchical service quality model for the travel and tourism industry. working paper N 06/18: University of Bradford, School of Management.

Chan, E. S. W., \& Wong, S. C. K. (2006). Hotel selection: when price is not the issue. Journal of Vacation Marketing, 12(2), 142-159.

Chitty, B., Ward, S., \& Chua, C. (2007). An application of the ECSI model as a predictor of satisfaction and loyalty for backpacker hostels. Marketing Intelligence \& Planning, 25(6), 563-580.

Choi, B. J., \& Kim, H. S. (2013). The impact of outcome quality, interaction quality, and peer-to-peer quality on customer satisfaction with a hospital service. Managing Service Quality, 23(3), 188-204.

Chou, T.-Y., Hsu, C.-L., \& Chen, M.-C. (2008). A fuzzy multi-criteria decision model for international tourist hotels location selection. International Journal of Hospitality Management, 27(2), 293-301.

Cronin Jr, J Joseph, Brady, Michael K, \& Hult, G Tomas M. (2000). Assessing the effects of quality, value, and customer satisfaction on consumer behavioral intentions in service environments. Journal of retailing, 76(2), 193-218

Cronin, J. J. J., \& Taylor, S. A. (1992). Measuring service quality: a reexamination and extension. the Journal of Marketing, 56(3), 55-68.

Dabholkar, P. A., \& Overby, J. W. (2005). Linking process and outcome to service quality and customer satisfaction evaluations: An investigation of real estate agent service. International journal of service industry management, 16(1), 10-27.

Ekinci, Y., Prokopaki, P., \& Cobanoglu, C. (2003). Service quality in Cretan accommodations: marketing strategies for the UK holiday market. International Journal of Hospitality Management, 22(1), 47-66.

Ekinci, Y., Riley, M., \& Fife-Schaw, C. (1998). Which school of thought? The dimensions of resort hotel quality. International Journal of Contemporary Hospitality Management, 10(2), 63-67.

Fassnacht, M., \& Koese, I. (2006). Quality of electronic services conceptualizing and testing a hierarchical model. Journal of Service Research, 9(1), 19-37.

Fornell, C. (1992). A national customer satisfaction barometer: the Swedish experience. Journal of Marketing, 56(1), 6-21.

Grönroos, C. (1984). A service quality model and its marketing implications. European Journal of Marketing, 18(4), 36-44.

Grönroos, C. (1990). Service management and marketing: managing the moments of truth in service competition. Lexington: MA.

Hair, J. F., Black, W. C., Babin, B. J., Anderson, R. E., \& Tatham, R. L. (2006). Multivariate data analysis (Vol. 6): Pearson Prentice Hall Upper Saddle River, NJ.

Hair, J. F., Money, A. H., Samouel, P., \& Page, M. (2007). Research methods for business. USA: John Wiley \& Sons. 
Han, X., Kwortnik, R. J., \& Wang, C. (2008). Service Loyalty An Integrative Model and Examination across Service Contexts. Journal of Service Research, 11(1), 22-42.

Hansen, K. V.(2005). The Meal Experiences of á la Carte Restaurant Customers, Scandinavian Journal of Hospitality and Tourism, 5(2), 135-151

Heskett, J. L., Sasser, W. E., \& Schlesinger, L. A. (1997). Service profit chain. New York: Free Press.

Hightower, R., Brady, M. K., \& Baker, T. L. (2002). Investigating the role of the physical environment in hedonic service consumption: An exploratory study of sporting events. Journal of Business Research, 55(9), 697-707.

Hooper, Daire, Coughlan, Joseph, \& Mullen, Michael R. (2008). Structural equation modelling: Guidelines for determining model fit. Electronic Journal of Business Research Methods, 6(1), 53-59.

Hsieh, \& Hiang, S. T. (2004). A study of the impacts of service quality on relationship quality in search-experience-credence services. Total Quality Management \& Business Excellence, 15(1), 687-688.

Hwang, J., \& Lambert, C. U. (2008). The interaction of major resources and their influence on waiting times in a multi-stage restaurant. International Journal of Hospitality Management, 27(4), 541-551.

Jones, P., \& Dent, M. (1994). Improving service: managing response time in hospitality operations. International Journal of Operations \& Production Management, 14(5), 52-58.

Keshavarz, Y., Ali M.H. (2015). The service quality evaluation on tourist loyalty in Malaysian hotels, Mediterranean Journal of Social Sciences, 6(3, S2), 680-686.

Keshavarz, Y., Ali M.H. (2015). The investigation of the hotels service quality effects on tourist Loyalty, International Journal of AYER, 2 , 327-342

Kim, K.-J., Park, J.-C., Park, Y.-J., Kim, C.-G., \& Kim, T.-H. (2007). The impact of network service performance on customer satisfaction and loyalty: High-speed internet service case in Korea. Expert Systems with Applications, 32(3), 822-831.

Kim, W. G., Ma, X., \& Kim, D. J. (2006). Determinants of Chinese hotel customers'e-satisfaction and purchase intentions. Tourism Management, 27(5), 890-900.

Knutson, B., Stevens, P., Wullaert, C., Patton, M., \& Yokoyama, F. (1990). LODGSERV: A service quality index for the lodging industry. Journal of Hospitality \& Tourism Research, 14(2), 277-284.

Ko, Y. J., \& Pastore, D. L. (2005). A Hierarchial Model of Service Quality for the Recreational Sport Industry. Sport Marketing Quarterly, 14(2), 84-97.

Kotler, P., Bowen, J. T., \& Makens, J. C. (1999). Marketing for Hospitality and Tourism (5 ed.). US: Pearson Hall.

Lai, F., Griffin, M., \& Babin, B. J. (2009). How quality, value, image, and satisfaction create loyalty at a Chinese telecom. Journal of Business Research, 62(10), 980-986.

Lehtinen, U., \& Lehtinen, J. R. (1982). Service quality: a study of quality dimensions: Service Management Institute.

Lloyd, A. E., Yip, L. S. C., \& Luk, S. T. K. (2011). An examination of the differences in retail service evaluation between domestic and tourist shoppers in Hong Kong. Tourism Management, 32(3), 520-533.

Lovelock, C. H. (1983). Classifying services to gain strategic marketing insights. the Journal of Marketing, 47(3), 9-20.

Luk, S. T.-K., \& Layton, R. (2004). Managing both outcome and process quality is critical to quality of hotel service. Total Quality Management \& Business Excellence, 15(3), 259-278.

Ministry of Torism Malaysia, [Online] vailable:http://www.tourism.gov.my/en/intl/places/states-of-malaysia/kuala-lumpur\#page1

Mattila, A. (1999). Consumers value judgments: How business travelers evaluate luxury-hotel services. The Cornell Hotel and Restaurant Administration Quarterly, 40(1), 40-46.

Mei, A. W. O., Dean, A. M., \& White, C. J. (1999). Analysing service quality in the hospitality industry. Managing Service Quality, 9(2), 136-143.

Mey, L. P., Akbar, A. K., \& Fie, D. Y. G. (2006). Measuring service quality and customer satisfaction of the hotels in Malaysia: Malaysian, Asian and non-Asian hotel guests. Journal of Hospitality and Tourism Management, 13(2), 144-160.

Mola, F., \& Jusoh, J. (2011). Service Quality in Penang Hotels: A Gap Score Analysis. World Applied Sciences Journal, 12 (S I), $19-24$.

Nadiri, H., \& Hussain, K. (2005). Perceptions of service quality in North Cyprus hotels. International Journal of Contemporary Hospitality Management, 17(6), 469-480.

Nilsson, W. L., \& Fundin. (2005). Dynamics of service attributes: a test of Kano's theory of attractive quality. International journal of service industry management, 16(2), 152-168.

Oh, H. (1999). Service quality, customer satisfaction, and customer value: A holistic perspective. International Journal of Hospitality Management, 18(1), 67-82.

Oliver, R. L. (1980). A cognitive model of the antecedents and consequences of satisfaction decisions. Journal of marketing research, 17(4), 460-469.

Oliver, R. L. (1999). Whence consumer loyalty. Journal of Marketing, 63(4), 33-44.

Olsen, S. O. (2007). Repurchase loyalty: the role of involvement and satisfaction. Psychology \& Marketing, 24(4), 315-341.

Parasuraman, A., Zeithaml, Valarie A., Berry, \& Leonard, L. (1988). SERVQUAL- A Multiple-Item Scale for Measuring Consumer Perceptions of Service Quality. Journal of Retailing, 64(1), 12-40.

Poon, W. C., \& Low, K. L. T. (2005). Are travellers satisfied with Malaysian hotels? International Journal of Contemporary Hospitality Management, 17(3), 217-227.

Powpaka, S. (1996). The role of outcome quality as a determinant of overall service quality in different categories of services industries: an empirical investigation. Journal of services Marketing, 10(2), 5-25. 
Rauyruen, P., \& Miller, K. E. (2007). Relationship quality as a predictor of B2B customer loyalty. Journal of Business Research, 60(1), 21-31.

Razalli, M. R. (2008). Service Delivery System Practices in Malaysian Hotel Operations: An Exploratory Study. Malaysian Management Journal, 12(1\&2), 103-115.

Reichheld, F. F., \& Sasser, W. E. (1990). Zero defections: quality comes to services. Harvard Business Review, 68(5), 105-111.

Rizal, Mohd Rizal (2008). Service delivery system practices in Malaysian hotel operations: An exploratory study. Malaysian Management Journal, 12(1\&2), 103-115.

Ro, H., Choi, Y., \& Olson, E. D. (2013). Service recovery evaluations: GLBT versus hetero customers. International Journal of Hospitality Management, 33, 366-375.

Saleh, F., \& Ryan, C. (1991). Analysing service quality in the hospitality industry using the SERVQUAL model. Service Industries Journal, 11(3), 324-345.

Siu, N. Y., \& Cheung, J. T.-H. (2001). A measure of retail service quality. Marketing Intelligence \& Planning, 19(2), 88-96.

So, K. K. F., King, C., Sparks, B., \& Wang, Y. (2013). The influence of customer brand identification on hotel brand evaluation and loyalty development. International Journal of Hospitality Management, 34, 31-41.

Tanford, S., Raab, C., \& Kim, Y.-S. (2012). Determinants of customer loyalty and purchasing behavior for full-service and limited-service hotels. International Journal of Hospitality Management, 31(2), 319-328.

Tsaur, S.-H., Chiu, Y.-C., \& Huang, C.-H. (2002). Determinants of guest loyalty to international tourist hotels-a neural network approach. Tourism Management, 23(4), 397-405.

Vesel, P., \& Zabkar, V. (2009). Managing customer loyalty through the mediating role of satisfaction in the DIY retail loyalty program. Journal of Retailing and Consumer Services, 16(5), 396-406.

Wilkins, H., Merrilees, B., \& Herington, C. (2007). Towards an understanding of total service quality in hotels. International Journal of Hospitality Management, 26(4), 840-853.

Wu, C. H.-J., \& Liang, R.-D. (2009). Effect of experiential value on customer satisfaction with service encounters in luxury-hotel restaurants. International Journal of Hospitality Management, 28(4), 586-593. doi: http://dx.doi.org/10.1016/j.jhm.2009.03.008

Wu, H.-C., \& Ko, Y. J. (2013). Assessment of service quality in the hotel industry. Journal of Quality Assurance in Hospitality \& Tourism, 14(3), 218-244.

Yang, Z., Peterson, R. T., \& Cai, S. (2003). Services quality dimensions of Internet retailing: an exploratory analysis. Journal of services Marketing, 17(7), 685-700.

Yoon, Y., \& Uysal, M. (2005). An examination of the effects of motivation and satisfaction on destination loyalty: a structural model. Tourism Management, 26(1), 45-56. 